\title{
RELATION OF THYROID AND PARATHYROID GLANDS TO CAL- CIUM AND PHOSPHORUS METABOLISM. STUDY OF A CASE WITH COEXISTENT HYPOPARATHYROIDISM AND HYPERTHYROIDISM
}

\author{
By OLIVER COPE AND GORDON A. DONALDSON \\ (From the Surgical Laboratories of the Harvard Medical School and the Thyroid Clinic at \\ the Massachusetts General Hospital, Boston)
}

(Received for publication November 23, 1936)

In a series of investigations on the relation of the thyroid to calcium and phosphorus metabolism Aub and his coworkers (1) have demonstrated that increased thyroid activity is associated with an increased excretion of calcium and phosphorus. In exophthalmic goiter there is an increased output of calcium not only in the urine but in the feces. In normal individuals who are fed thyroid there is a similar increase in calcium and phosphorus excretion, and in myxedema there is a diminished excretion which rises toward normal following thyroid therapy. This increase in negative calcium and phosphorus balance is dissimilar to that produced by overactivity of the parathyroid glands. In hyperparathyroidism the fecal calcium excretion is not increased in the absence of kidney damage (2). The blood levels of both calcium and phosphorus are altered in hyperparathyroidism while in hyperthyroidism they are usually within normal limits. These workers have also demonstrated improvement in tetany of hypoparathyroid origin from thyroid medication with an elevation of the lowered blood calcium level toward that of normal (3). Careful total acid-base balance experiments have excluded in their opinion acidosis as a cause of this altered metabolism (4). Vitamin D deficiency has also been studied as a possible cause and has been considered excluded (5). The conclusion of these workers is that if the blood calcium level is below normal before medication an increased amount of the thyroid hormone releases calcium and phosphorus from the bones with a consequent rise of the blood calcium level and an increased excretion of both calcium and phosphorus by the kidney and large bowel. The usual absence of altered blood levels of both calcium and phosphorus, together with the increased fecal calcium excretion, lead them to believe that in hyper- thyroidism a concomitant overactivity of the parathyroid glands is not present. These conclusions have recently been challenged by Hansman and Wilson (6) in a series of studies on patients with hyperthyroidism, two of whom also had postoperative hypoparathyroidism. These Australian workers believe that in thyrotoxicosis there is an associated overactivity of the parathyroid glands and that the alterations in calcium and phosphorus metabolism are directly due to the excessive parathyroid secretion.

The appearance of a patient in the Thyroid Clinic with postoperative parathyroid tetany and a recrudescence of her exophthalmic goiter presented us with an unusual opportunity to study the interrelation of the thyroid and parathyroid glands in their control of calcium and phosphorus metabolism.

\section{METHODS}

The metabolic studies of calcium and phosphorus were carried out in periods of three days each, according to the routine developed on the metabolism ward of this hospital by Bauer and Aub (7). Both the dietary and fluid intake were identical for all seven periods except that extra sugar was allowed the patient in Periods V to VII. The diet was neutral in its acid-base contents. The constituents were not actually analyzed but were calculated from previous analyses of standard foodstuffs used on the metabolism ward. The calcium and phosphorus in both blood serum and the excreta were determined by the Fiske methods $(8,9)$. In order to avoid an increase in inorganic phosphate from organic phosphate (10), the blood for all phosphorus determinations was taken under oil and the determinations started immediately. Magnesium was determined by a modification of the Handy method (11). Phosphatase is recorded in Bodansky units (12). The remaining determinations were made by standard laboratory procedures. The blood chloride and carbon dioxide determinations were made on arterial blood taken under oil.

\section{SUMMARY OF HISTORY}

The observations were carried out on E. M. G., an unmarried woman of twenty-seven. (A complete protocol 


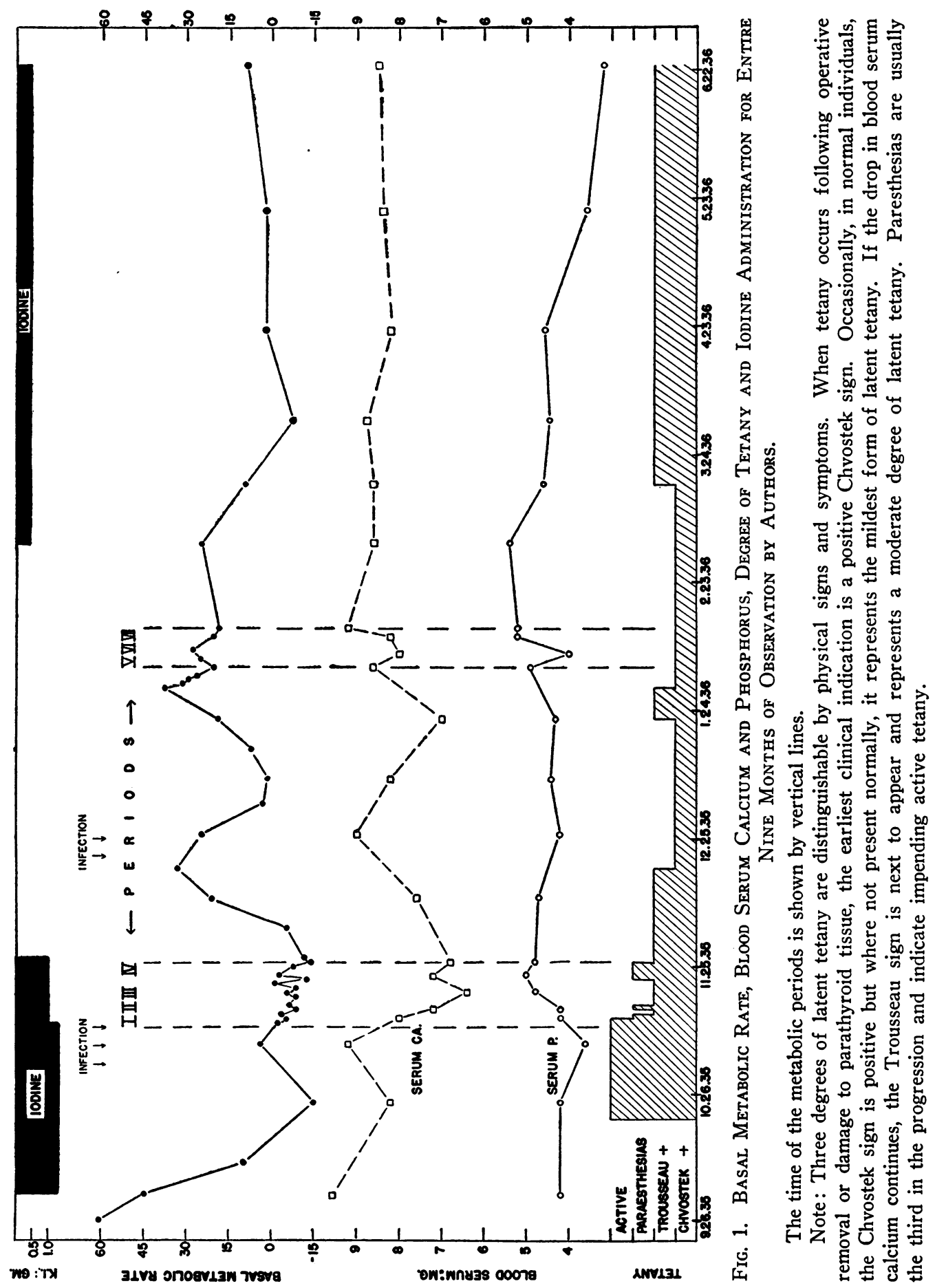


of the history and findings on this patient is appended and reference should be made to it for details.) She first came to the Clinic in September 1932 with typical hyperthyroidism of moderate severity. Immediately following subtotal thyroidectomy, tetany of parathyroid origin appeared. During the next two and one-half years mild tetany continued to be almost completely controlled by calcium lactate ingestion. A recrudescence of thyrotoxicosis was established in April 1933, and from that time until December 1934 the thyroid activity was held within normal limits by iodine. In order to help control the mild chronic tetany, iodine was discontinued in December 1934 and her metabolic rate slowly rose to +35 over a period of four months. At the end of this rise, it was noted that her tetany had disappeared and calcium medication was omitted. Regrowth of thyroid tissue and increase of thyrotoxicosis continued to occur until on September 26, 1935, her metabolic rate had reached +61 and a full-blown recrudescence of thyrotoxicosis, including exophthalmos, was apparent. At this time she first came under the observation of the authors. It was realized that control of the thyrotoxicosis with iodine was likely to cause an abrupt reappearance of parathyroid tetany. At this point, therefore, calcium and phosphorus studies were started, which will be considered in detail.

Figure 1 shows the changes in metabolic rate during the period of observation by the authors, together with the blood serum calcium and phosphorus and the clinical degree of tetany. At the height of the recrudescence of thyrotoxicosis on October 2, 1935, the serum calcium was $9.6 \mathrm{mgm}$. and serum phosphorus $4.2 \mathrm{mgm}$. Clinical signs of tetany were absent. Iodine was started on this date with a fall in metabolic rate to +10 on October 10th, and -15 on October 24th. Completely relieved of her symptoms of thyrotoxicosis and feeling unusually well, on October 20th an attack of tetany suddenly appeared. For the next two weeks, until her entry into the hospital, daily attacks of mild tetany occurred in spite of high calcium medication with viosterol.

On November 6, 1935, the patient entered the metabolism ward for the first series of observations. The thyrotoxicosis was under complete control with iodine by mouth. Potassium iodide, $1 \mathrm{gram}$, was given daily. Four days before entry, she acquired an acute upper respiratory infection. With the infection she noticed increased tetanic spasms, and, on the day of entry, she was having active tetany.

In spite of the tetany she was placed on the standard low calcium diet for five days preceding the first day of observation. Intravenous and intramuscular calcium gluconate was given in sufficient quantities to control the tetany. Active tetany disappeared coincidently with the bronchitis and upper respiratory infection, and calcium gluconate was discontinued after the first day of the first period.

During the fifteen days covering the time of the four periods observed during the iodine induced remission, the patient continued to have more or less constant numb- ness and tingling of the extremities. There were occasional cramps involving the small muscles of the thumbs and also the feet. The Chvostek and Trousseau signs were positive throughout.

Following these first four periods iodine was discontinued, and the patient was allowed to go home on a low calcium diet. The metabolic rate was observed weekly. The thyrotoxicosis recurred promptly. When the metabolic rate was above 30 the patient developed another acute respiratory infection which apparently initiated a spontaneous remission. In two weeks the metabolic rate dropped nearly to normal. There was no evidence that the patient had received iodine in any form. The patient was very coöperative and intelligent and ate only those things allowed in her diet. A study of the only medication taken on her own initiative showed it to contain no iodine. Following this unusual remission the metabolic rate again rose over a period of three weeks to +37 on January 29,1936 . On this day she was again admitted to the metabolism ward where, after a preliminary four days under standard conditions, three threeday periods were observed.

No iodine was given during this entry. Daily determinations showed a metabolic rate continuously 20 per cent above normal. Signs and symptoms of thyrotoxicosis were present. Although she had occasional sensations of numbness, there was no active tetany similar to that observed during the period of observation under iodine control. The Trousseau sign throughout was negative, but of note was a continuously positive Chvostek. The electrical reactions still showed the diminished threshold consistent with tetany.

After the metabolic studies were complete, iodine was again given. A prompt fall in metabolic rate to just below normal, typical of an iodine remission, proved the existence of true thyrotoxicosis. Mild tetany reappeared. Subsequently, the tetany has been controlled with large doses of viosterol and a high calcium, low phosphorus diet. The metabolic rate has remained within normal limits, the patient receiving iodine daily.

\section{OBSERVATIONS}

Calcium and phosphorus metabolism. Figure 2 shows graphically the metabolic balances of calcium and phosphorus. The metabolic rate and the blood serum levels of calcium and phosphorus for each period are given. Table I gives the actual figures for the intake and excretion of calcium and phosphorus, together with the metabolic rate and the excretion of nitrogen and potassium. In the first four periods positive balances of calcium and phosphorus were found. On this standard diet a slightly negative balance of both calcium and phosphorus is observed in normal individuals (13). The urinary excretion of calcium in the normal controls averages 170 


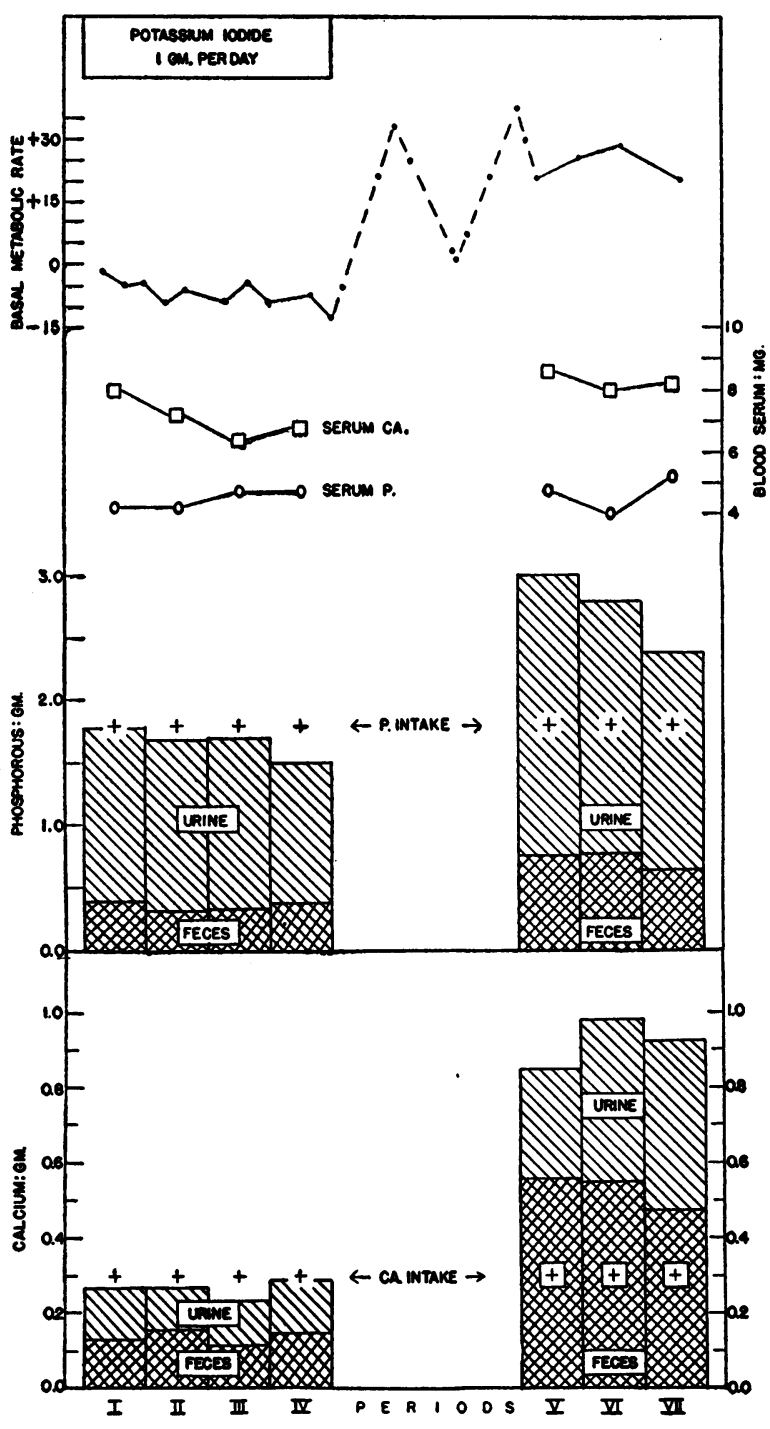

Fig. 2. Calcium and Phosphorus Balances, together with Metabolic Rate, Blood Serum Calcium and Phosphorus Values for Each Period.

mgm. and the fecal excretion $350 \mathrm{mgm}$. In the controls in nitrogen equilibrium, the negative phosphorus balance is about half that of the calcium. The positive balance of both calcium and phosphorus observed in this patient during the iodine induced remission is characteristic of decreased parathyroid function. This was to be expected since the thyrotoxicosis was completely controlled and active tetany was present. It is interesting that the actual excretions in Period I were as low as in the succeeding three periods in spite of the parenterally administered calcium gluconate used to control the tetany.
The last three Periods, V, VI and VII, observed during the recrudescence of thyrotoxicosis, show abnormally high negative calcium and phosphorus balances. With the same intake of calcium, the total excretion was nearly double that seen in normal controls and represents an increase of 247 per cent over the previous periods. This increase in calcium excretion took place both in the urine and feces. Although the percentage increase in both was about the same, the actual increase was much greater in the feces. The fecal excretion was also nearly double the dietary intake of calcium and it is obvious, therefore, that a true intestinal excretion occurred.

The increased excretion of phosphorus in the last three periods was more than would be expected from the increase in calcium excretion alone. A negative balance of calcium indicates withdrawal of calcium from the body stores. Since the only available store is in the bones (14), where it is deposited as phosphate and carbonate, release of calcium should be accompanied by a proportionate release of phosphate. If apatite (15) is taken as the bone salt, the calcium to phosphorus ratio is 2.26 , and the increased calcium excretion would, therefore, account for 290 $\mathrm{mgm}$. of the $1057 \mathrm{mgm}$. average increase observed in phosphorus excretion per period.

The remainder of the increase in phosphorus excretion found during thyrotoxicosis is quantitatively accounted for by the increased nitrogen excretion of 12.0 grams per period. The dietary intake was identical for all seven periods, except that during the three of increased metabolic rate, sugar and sugar candy in excess of the weighed diet were allowed the patient in the hope of meeting the increased caloric requirement. Although the weight of the patient was essentially maintained during the last three periods, the above increase in urinary nitrogen occurred. That this nitrogen increase was at the expense of body cellular protein is confirmed by the increase in potassium excretion. As with the withdrawal of calcium from bone, so the breakdown of body protein is accompanied by release of phosphorus as well as nitrogen. From the ratio $\mathrm{N} / \mathrm{P}=17.4$, derived from Benedict's fasting man (16), the nitrogen equivalent of the increased phosphorus excretion equals $689 \mathrm{mgm}$. This nitrogen equiva- 
TABLE I

Metabolic data (Values in grams per three day period)

\begin{tabular}{|c|c|c|c|c|c|c|c|c|c|c|c|c|c|c|}
\hline \multirow{3}{*}{ Period } & \multirow{3}{*}{ Medication } & \multicolumn{4}{|c|}{ Phosphorus } & \multicolumn{4}{|c|}{ Calcium } & \multirow{3}{*}{$\begin{array}{c}\begin{array}{c}\text { Nitro- } \\
\text { gen }\end{array} \\
\\
\begin{array}{c}\text { Urinary } \\
\text { excre- } \\
\text { tion }\end{array}\end{array}$} & \multirow{2}{*}{\multicolumn{2}{|c|}{$\frac{\text { Potassium }}{\text { Output }}$}} & \multirow{3}{*}{$\begin{array}{l}\text { Average } \\
\text { B.M.R. }\end{array}$} & \multirow{3}{*}{$\begin{array}{l}\text { Aver- } \\
\text { age } \\
\text { weight }\end{array}$} \\
\hline & & \multirow{2}{*}{ Intake } & \multicolumn{2}{|c|}{ Output } & \multirow{2}{*}{ Balance } & \multirow{2}{*}{ Intake } & \multicolumn{2}{|c|}{ Output } & \multirow{2}{*}{ Balance } & & & & & \\
\hline & & & Urine & Feces & & & Urine & Feces & & & Urine & Feces & & \\
\hline $\begin{array}{l}\text { II } \\
\text { II } \\
\text { III } \\
\text { IV }\end{array}$ & $\mid \begin{array}{l}3 \text { grams K.I. } \\
3 \text { grams K.I. } \\
3 \text { grams K.I. } \\
3 \text { grams K.I. }\end{array}$ & $\begin{array}{l}\text { grams } \\
1.788 \\
1.788 \\
1.788 \\
1.788\end{array}$ & $\begin{array}{l}\text { grams } \\
1.396 \\
1.366 \\
1.365 \\
1.118\end{array}$ & $\begin{array}{l}\text { grams } \\
.385 \\
.323 \\
.334 \\
.385\end{array}$ & $\begin{array}{c}\text { grams } \\
+.007 \\
+.099 \\
+.089 \\
+.285\end{array}$ & $\begin{array}{l}\text { grams } \\
.300^{*} \\
.300 \\
.300 \\
.300\end{array}$ & $\begin{array}{l}\text { grams } \\
.121 \\
.109 \\
.118 \\
.147\end{array}$ & $\begin{array}{l}\text { grams } \\
.146 \\
.164 \\
.118 \\
.136\end{array}$ & $\begin{array}{l}\text { grams } \\
+.033 \\
+.027 \\
+.064 \\
+.017\end{array}$ & $\begin{array}{l}\text { grams } \\
20.2 \\
19.6 \\
20.2 \\
17.5\end{array}$ & $\begin{array}{l}\text { grams } \\
5.114 \\
5.114 \\
5.083 \\
4.500\end{array}$ & \begin{tabular}{r|} 
grams \\
.702 \\
.508 \\
.626 \\
1.095
\end{tabular} & $\begin{array}{l}\text { per cent } \\
-4 \\
=8 \\
=8 \\
-11\end{array}$ & $\begin{array}{l}\mathrm{kgm} . \\
57.4 \\
57.9 \\
58.3 \\
57.8\end{array}$ \\
\hline Average & 3 grams K.I. & 1.788 & 1.311 & .357 & +.120 & .300 & .124 & 141 & +.035 & 19.4 & 4.953 & .733 & -8 & 57.9 \\
\hline $\begin{array}{r}\mathrm{V} \\
\mathrm{VI} \\
\mathrm{VII}\end{array}$ & $\begin{array}{l}\mathbf{0} \\
\mathbf{0} \\
\mathbf{0}\end{array}$ & $\begin{array}{l}1.788 \\
1.788 \\
1.788\end{array}$ & $\begin{array}{l}2.280 \\
2.030 \\
1.737\end{array}$ & $\begin{array}{l}.740 \\
.751 \\
.636\end{array}$ & $\begin{array}{l}-1.232 \\
-\quad .993 \\
-.585\end{array}$ & $\begin{array}{l}.300 \\
.300 \\
.300\end{array}$ & $\begin{array}{l}.304 \\
.430 \\
.460\end{array}$ & $\begin{array}{l}.555 \\
.550 \\
.465\end{array}$ & $\begin{array}{l}-.559 \\
-.680 \\
-.625\end{array}$ & $\begin{array}{l}32.7 \\
32.3 \\
29.1\end{array}$ & $\begin{array}{l}7.036 \\
5.895 \\
5.395\end{array}$ & $\begin{array}{l}1.330 \\
1.130 \\
1.210\end{array}$ & $\begin{array}{l}+23 \\
+28 \\
+20\end{array}$ & $\begin{array}{l}54.7 \\
53.9 \\
54.0\end{array}$ \\
\hline Average & 0 & 1.788 & 2.016 & .709 & -.937 & .300 & .398 & .523 & -.621 & 31.4 & 6.109 & 1.223 & +24 & 54.2 \\
\hline
\end{tabular}

* This figure represents only the total dietary intake. On the first day of this period 1 gram of calcium gluconate was given intramuscularly which was not included in this total. The actual positive balance for the first period was therefore greater than recorded.

lent together with the calcium equivalent leaves but $78 \mathrm{mgm}$. of the increase in phosphorus excretion unaccounted for. This discrepancy is well within the limit of error in a balance experiment.

It is interesting that in this patient the increased phosphorus excretion during thyrotoxicosis occurred in the feces as well as in the urine. In all the patients studied by Aub et al. with either primary thyrotoxicosis or that induced by thyroid extract, the increased excretion of phosphorus was limited to the urine.

Levels of calcium and phosphorus in the blood serum. In Figure 1 it will be observed that the blood serum calcium level was in general higher when hyperthyroidism existed than when a normal metabolism had been induced by iodine. Although the curves of the blood calcium level and the metabolic rate are parallel throughout, the blood calcium rose and fell nearly two weeks after the corresponding changes in metabolic rate. A similar delay in change of the serum calcium level behind the metabolic rate was noted by Aub, Albright, Bauer, and Rossmeisl (3) in the second of the two patients with hypoparathyrodism treated with thyroxin. At the end of October the delayed fall in blood calcium was in all probability influenced by the high calcium medications given during active tetany and perhaps also by the respiratory infection. Until the end of Janu- ary 1936, the phosphorus changed inversely to the serum calcium and metabolic rate. During the period of thyrotoxicosis, however, the serum phosphorus rose slightly, parallel to the blood calcium. It is doubtful that the excretion of calcium is dependent upon the total serum calcium level since in Periods I to IV the excretion of calcium is essentially the same while the blood levels varied from 8.0 to $6.4 \mathrm{mgm}$. The increased excretion in Periods V to VII occurred with a serum calcium level from 8.0 to $8.6 \mathrm{mgm}$. The average blood phosphorus level for the first four periods was $4.5 \mathrm{mgm}$. and for the last three, $4.7 \mathrm{mgm}$. It is equally doubtful that the change in phosphorus excretion could be dependent upon this minor change in the serum phosphate level.

Tetany. At the base of Figure 1 the amount of clinical tetany is shown graphically.

Tetany of parathyroid origin may be divided into active and latent. In this patient the tetany was not severe and active tetany on the chart represents merely moderate though painful spasms. Latent tetany is subdivided into three categories according to severity. These are based on observation of the 35 cases of hyperparathyroidism operated upon at this hospital as well as cases of tetany observed following thyroid operation.

In the week immediately preceding Period I, 
when active tetany occurred, the blood calcium was above $8.0 \mathrm{mgm}$. During the first three periods, as the tetany improved, the blood calcium level fell, and when the lowest blood calcium level was reached at $6.4 \mathrm{mgm}$. in Period III, active tetany and paresthesias had disappeared, only positive Trousseau and Chvostek signs being present. This improvement in tetany with a concurrent fall in blood serum calcium is the reverse of what usually happens in tetany of parathyroprivic origin.

It is currently believed that the tetany associated with diminished parathyroid function is due to a lowered level of the dissociated or ionic calcium of the blood serum and not to any alteration in amount of the protein bound fraction. Direct serum calcium partitions were not done on this patient. In normal individuals indirect evidence of the calcium partition can be obtained from the concentration of serum protein to which the undissociated calcium is bound quantitatively and from the level of the spinal fluid calcium which is believed to represent the filtrable or ionized equivalent of the blood serum. Sufficient determinations of serum protein and spinal fluid calcium were not made to explain the paradoxical relation of total serum calcium to degree of tetany. It will be observed from the figures in Table II that during the period of iodine induced remission, when the tetany was more active, the serum protein was slightly more elevated and the spinal fluid calcium was $1.4 \mathrm{mgm}$. lower than during thyrotoxicosis.

It is probable that the tetany was influenced by the upper respiratory infection since the active tetany disappeared at the same time as the signs of infection. A similar increase in the severity of tetany of parathyroid origin, induced by an acute upper respiratory infection, has been noticed in the series of cases of hyperparathyroidism from this hospital (17). In one of the two cases of hypoparathyroidism observed by Aub et al. (3), acidosis produced by ammonium chloride improved the tetany. An acidosis however was not found in our patient during the active tetany. The arterial blood carbon dioxide combining power and content, serum chloride and sodium, taken during active tetany, showed no significant changes. In order to exclude tetany due to over- ventilation, rebreathing was tried during active spasms. No noticeable effect was obtained.

Throughout this study tetany became less intense with an increase of thyroid activity. This improvement was consistent with the slight elevation of the blood calcium during the thyrotoxic state. It is important to note that except at the very beginning of our observations some degree of tetany was always present. From the first appearance of tetany following iodine administration, the Chvostek sign was continuously present, even during the recrudescence of thyrotoxicosis. The patient had no tetany when the metabolic rate was +45 to +61 and the general clinical picture of thyrotoxicosis was moderately severe. When the metabolic observations were made during the reappearance of thyrotoxicosis, not only was the metabolic rate lower than when tetany was absent, but the clinical signs and symptoms of the thyroid disease were milder. During Periods V to VII, had the degree of thyrotoxicosis been more severe, it is probable that tetany might have been completely absent and the blood calcium been further elevated. It is fortunate that the clinical signs of tetany were not completely eliminated by a more active hyperthyroidism since the presence of tetany gives a clue to the degree of function of the parathyroid glands and excludes the parathyroids as the source of the metabolic changes found.

The probability that tetany of hypoparathyroid origin was latent throughout both groups of observations depends not merely upon the clinical signs but also on the electrical threshold reactions. On November 12, 1935, Period I, 1 milliampere was required on closing for face and eyelid muscles and 2 milliamperes for the extensor digitorum communis. Opening currents were 3 and 4 milliamperes respectively. Two normal controls checked at the same time required an average of double this amount. On March 4, 1936 , when the metabolic rate was +25 , the responses of the face and forearm muscles were obtained with currents actually somewhat lower than at the previous observations.

\section{DISCUSSION}

The studies of the calcium and phosphorus balance made on this patient confirm the findings of 


\begin{tabular}{|c|c|c|c|c|}
\hline \multirow{3}{*}{\multicolumn{2}{|c|}{ 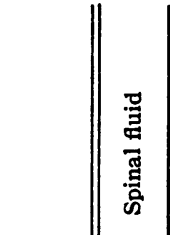 }} & \multirow{2}{*}{$\frac{\sum^{\infty}}{\sigma}$} & \multicolumn{2}{|r|}{$\stackrel{\infty}{-}$} \\
\hline & & & $\dot{8} \dot{8}$ & $\stackrel{m}{\approx}$ \\
\hline & & 客起 & ह & $\stackrel{n}{\rightarrow}$ \\
\hline \multirow{5}{*}{\multicolumn{2}{|c|}{ 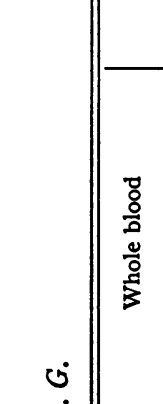 }} & లீ & 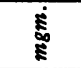 & $\stackrel{n}{m}$ \\
\hline & & 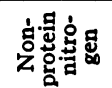 & 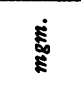 & เ \\
\hline & & 离 & 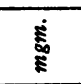 & $\stackrel{\text { og }}{0}$ \\
\hline & & 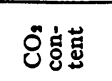 & 龍 & $\stackrel{a}{\sharp}$ \\
\hline & & ठํ. & "ू. & 吕 \\
\hline \multirow{13}{*}{ 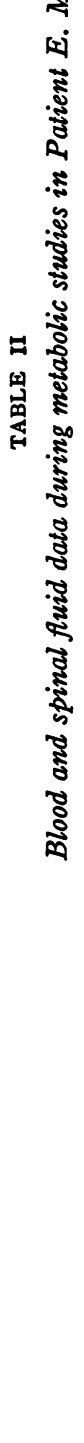 } & \multirow{7}{*}{ 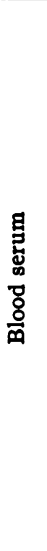 } & $\tilde{z}$ & ह & $\stackrel{\mathscr{m}}{\rightarrow}$ \\
\hline & & ర & $\dot{8}$ & $\hat{0} \quad \tilde{0}$ \\
\hline & & $\sum_{\Sigma}^{\infty}$ & 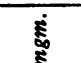 & $\stackrel{\circ}{m}$ \\
\hline & & i⿱宀⿻心㇒⿻ & $\$$ & ดे ต்ุ \\
\hline & & 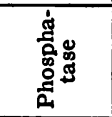 & 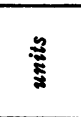 & 혛 \\
\hline & & 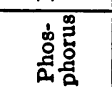 & 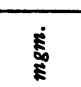 & 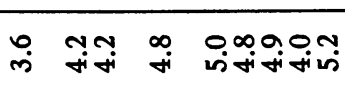 \\
\hline & & లో & $\dot{\delta}$ & 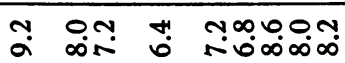 \\
\hline & \multicolumn{2}{|r|}{ 密 } & & 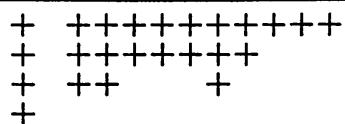 \\
\hline & \multicolumn{2}{|c|}{ 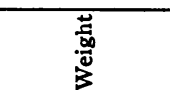 } & 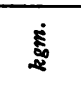 & 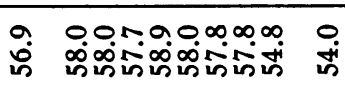 \\
\hline & \multicolumn{2}{|r|}{ : } & \& & $\begin{array}{l}+ \text { manbamtio } \\
+\quad 1111111+\end{array}$ \\
\hline & \multicolumn{2}{|r|}{ 总 } & & 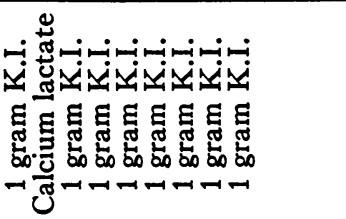 \\
\hline & & कृष्ठ & & 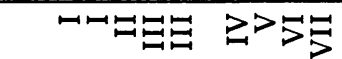 \\
\hline & \multicolumn{2}{|r|}{ ด็ } & & 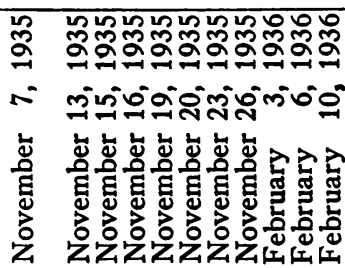 \\
\hline
\end{tabular}


Aub and his coworkers. The marked increase in calcium and phosphorus excretion to above normal, occurring during the time of increased metabolic rate with signs of thyrotoxicosis and continued tetany, lends substantial support to the belief that the increased excretion in hyperthyroidism is not due to a concomitant overactivity of the parathyroid glands. It is probable that the parathyroid function was still somewhat below normal although the tetany was improved and the serum calcium level slightly raised toward normal by the increased thyroid function. A positive Chvostek sign and diminished electrical threshold response are not proof of hypoparathyroidism. It is, however, unlikely since the blood serum calcium was still below normal that any overactivity of the parathyroids occurred. This rise in blood calcium and improvement in tetany was observed by Aub et al. (3) upon giving thyroid extract to patients with hypoparathyroidism.

Thyroid extract does not duplicate the disease of hyperthyroidism. Whatever the stimulus is which produces thyroid hyperplasia and increased excretion of the thyroid hormone, be it the anterior pituitary or excessive cervical sympathetic stimulation directly to the thyroid, this stimulus probably is not set in motion when thyroid extract or thyroxin is administered. It is possible that the same stimulus which causes overactivity of the thyroid gland in hyperthyroidism might cause overactivity of the parathyroids. Administration of thyroid extract or thyroxin is essentially a replacement therapy of the thyroid alone and would not necessarily stimulate parathyroid secretion. In the patient reported in this study the increased metabolism occurred from endogenous thyroid hormone. The production of the increased thyroid activity was caused by the stimulus of the disease. If the parathyroid glands are stimulated to overactivity by the disease stimulus in hyperthyroidism, increased activity of the parathyroid glands should have occurred in this patient. It is possible that slight increase in activity of the remaining parathyroid tissue did occur, but if it did, the total parathyroid activity was in all probability still below normal since tetany and a subnormal blood calcium persisted. Any change in the calcium and phosphorus me- tabolism due to change in the parathyroid activity would still have been, therefore, in the range of hypoparathyroidism. The shift of the excretions to amounts well above normal which did occur with the recrudescence of the hyperthyroidism, the blood calcium remaining below normal, is certainly not characteristic of hyperparathyroidism, and the contentions of Hansman and Wilson (6) are not upheld.

It is still not proven that the entire inorganic metabolic change is due to the altered thyroid activity since the stimulus of the disease in itself might be responsible for part. If the pituitary were primarily responsible for hyperthyroidism, as is currently held by some workers, the increased negative balances of calcium and phosphorus might be due directly to increased anterior pituitary secretion.

Aub (18) has recently shown that pituitary basophilism with osteoporosis is associated with an increased output of calcium and phosphorus in the urine. This abnormal excretion returns to normal following $x$-ray treatment of the pituitary with relief of the disease. He found no increase in the fecal excretion. Aub (19) has studied cases of acromegaly in which he found an increased negative calcium and phosphorus balance, the abnormal excretion being almost entirely limited to the urine. Calcium and phosphorus metabolism of a patient with adrenal cortical carcinoma simulating pituitary basophilism has been studied in this hospital by Albright (20). As in the pituitary diseases, an increased excretion of calcium and phosphorus in the urine but not in the feces was found. In cases both of pituitary basophilism and of adrenal cortical carcinoma the metabolic rate was below normal. The cause of the abnormal excretion was, therefore, probably not increased thyroid activity. In acromegaly there is at times increased thyroid activity, and this might in part explain the abnormal excretion in that disease. The occurrence of abnormal calcium and phosphorus metabolism associated not only with overactivity of the parathyroid glands but also of the thyroid, anterior pituitary and adrenal cortex, suggests that calcium metabolism like carbohydrate metabolism is influenced by a balance between various endocrine glands.

As the knowledge of the parathyroid glands 
developed it became almost an assumption that their function was the control of calcium within the body. The first challenge of this assumption was the demonstration by Aub and his coworkers of the profound effect upon calcium and phosphorus produced by changes in thyroid function. The specific rôles of the various hormones affecting calcium or phosphorus are doubtless different even though the effect upon the total metabolic change may be the same. To date, only two outstanding differences in the function of these glands have been demonstrated. The first is the control of the blood levels of calcium and phosphorus by parathyroid activity. The second is the increased fecal excretion in hyperthyroidism. Only in hyperparathyroidism with marked renal damage is a similar increase in the excretion of calcium found in the feces. In this condition, the kidney apparently is no longer able to take care of the abnormal outflow of calcium, and the assumption by the bowel of this task represents an abnormality of the disease itself. The demonstration of an abnormal balance of calcium or phosphorus no longer points, therefore, to one specific disease entity.

In the patient reported in this paper an increased phosphorus excretion as well as that of calcium, demonstrated during active hyperthyroidism, has been found in the feces for the first time. Its meaning or significance is not evident.

\section{SUMMARY}

A study of the calcium and phosphorus metabolism has been made in a patient suffering from recurrent thyrotoxicosis and postoperative parathyroid tetany. When the metabolic rate was maintained within normal limits with iodine medication the calcium and phosphorus metabolic balances were characteristic of parathyroid tetany. During hyperthyroidism a marked increase in the negative balance of calcium and phosphorus beyond normal limits was found even though signs of diminished parathyroid activity continued.

Increased thyroid activity was followed by a rise of the subnormal blood serum calcium level toward that of normal and a decrease in the signs of tetany. The reverse occurred with a decrease in thyroid function.

An acute upper respiratory infection was as- sociated with an increase in the amount of clinical tetany and also with a spontaneous remission of the thyrotoxicosis.

Because of the probably continued subnormal activity of the parathyroid glands it is concluded that the changes of calcium and phosphorus metabolism were due to the changes in thyroid function. Further support is given to the belief that the changes in calcium metabolism previously reported in hyperthyroidism are not due to a concomitant overactivity of the parathyroid glands.

A discussion of the relation of the parathyroid, thyroid, anterior pituitary and adrenal cortical glands in calcium metabolism is given.

\section{PROTOCOL}

E. M. G., female, age 23, M. G. H. number 323612 , metabolism number 10759, entered the hospital August 31, 1932, complaining of painless swelling of the neck of one month's duration. During the past year she had noted slight, gradually increasing nervousness. Huskiness and occasional cough had been noted for two months. One month before entry patient had had onset of slight dyspnea on exertion but no palpitation. She had been told her eyes were stary. She had always perspired a good deal; warm weather was well tolerated. She had noted no tremor.

Four years ago following tonsillectomy patient noticed a swelling of her neck which disappeared without treatment. Two years ago and again one year ago antrum had been operated upon. Since second antrum operation she had gained 18 pounds in weight. There have been occasional morning headaches and regular nocturia of one time. Catamenia was regular. Poor financial situation, otherwise past and family histories were non-contributory.

Examination showed an alert young woman with warm moist skin; no eye prominence or lid lag but definite stare. Thyroid was large, uniform, soft, with both thrill and bruit. There was slight tremor of extended fingers, heart was normal and blood pressure 150/80.

Examinations of blood, urine and stool were essentially negative.

$\mathrm{X}$-ray of chest showed shadow of thyroid extending downward beneath manubrium; trachea not displaced or narrowed. Lung markings were prominent with no evidence of consolidation; heart shadow was not remarkable.

Basal metabolic rate on entry was +50 per cent, dropping on rest alone to +39 and +35 . Weight was 55.7 $\mathrm{kgm}$. After iodine the rate dropped to +3 by September 10th.

September 12, 1932, subtotal thyroidectomy was performed. A radical excision is recorded. Pathological report: marked hyperplasia of the epithelial elements; 
unusually little lymphoid infiltration and no definite evidence of involution. Tissue weighed 95 grams.

Two days after operation carpopedal spasm and paresthesias appeared. Chvostek and Trousseau signs were positive. The following morning serum calcium was 6.3 mgm., serum phosphorus $4.2 \mathrm{mgm}$. A high calcium intake was started. Signs of active tetany were absent two days later. Trousseau and Chvostek signs remained positive. On ninth postoperative day metabolic rate was -16. Patient was discharged from hospital September 22, 1932; diagnosis, exophthalmic goiter; complication, tetany.

\section{Follow-up observations}

In the interval from October 26, 1932, to September 26, 1935, the patient made the following sixteen visits to the Outpatient Thyroid Clinic:

October 26, 1932, B. M. R. was +5 , Chvostek plus, Trousseau plus, serum calcium $7.7 \mathrm{mgm}$., and serum phosphorus $4.2 \mathrm{mgm}$. Patient was placed on calcium lactate by mouth.

December 8, 1932, B. M. R. was -7. There were occasional paresthesias and cramps in the right arm; Chvostek and Trousseau were negative.

February 9, 1933, B. M. R. was +8. Patient was still having cramps and paresthesias in spite of calcium lactate. Pyramidal lobe and small irregular lump in region of left thyroid lobe were palpable. Serum calcium was $8.3 \mathrm{mgm}$., and serum phosphorus $3.5 \mathrm{mgm}$.

April 20, 1933, B. M. R. was + 17. Patient was still taking calcium lactate. There were no symptoms of tetany, Chvostek was positive. Lugol's, minims 3 daily, was started.

June 22, 1933, B. M. R. was - 14; weight $58.7 \mathrm{kgm}$.

September 14, 1933, B. M. R. was + 1. Patient was still taking calcium lactate and Lugol's.

December 14,1933 , B. M. R. was +10 , serum calcium $8.7 \mathrm{mgm}$., and serum phosphorus $3.4 \mathrm{mgm}$.

March 15, 1934, B. M. R. was +20.

June 14, 1934, B. M. R. was + 9. Patient complains of recurrent nervousness, occasional numbness of left hand. Chvostek was negative and Trousseau strongly positive in two minutes. Iodine was increased, calcium lactate continued.

September 13, 1934, B. M. R. was -12 , weight 53.5 $\mathrm{kgm}$. Patient was less nervous with no symptoms of tetany. Chvostek and Trousseau were negative. Thyroid nodule on left was recorded as $3 \times 3 \mathrm{~cm}$., on right $1 \times 1 \mathrm{~cm}$. with $0.5 \mathrm{~cm}$. pyramidal lobe. There was slight exophthalmos and no lid lag.

December 13, 1934, B. M. R. was +6. Only 1 to 2 drops of potassium iodide a week had been taken since last visit; calcium was continued.

February 14, 1935, B. M. R. was +26 , weight 56.0 $\mathrm{kgm}$. No iodine had been taken since last visit; patient has continued taking calcium lactate. Chvostek and Trousseau were negative. Impression, tetany free, recurrent toxicity; omit calcium.

March 14, 1935, B. M. R. was +36 .

April 11, 1935, B. M. R. was +22 . Tetany free.
May 23, 1935, B. M. R. was + 39. Patient was increasingly nervous, Chvostek and Trousseau were negative.

July 25,1935 , B. M. R. was +26 , weight $51.6 \mathrm{kgm}$.

September 26, 1935, B. M. R. was +61, pulse 126, weight $56.1 \mathrm{kgm}$. At this visit the patient was seen for the first time by the authors. She was definitely jumpy, overactive, and presented the picture of full-blown thyrotoxicosis. There was definite tremor. In contrast to the time of operation there was now a moderate but definite exophthalmos with no lid lag, a normal convergence, but a definite stare. A regrowth of thyroid tissue on both sides, more marked at the left upper pole, was evident. Chvostek and Trousseau signs were negative.

October 2, 1935, B. M. R. was +45 , serum calcium $9.6 \mathrm{mgm}$., and serum phosphorus $4.2 \mathrm{mgm}$. Patient was started on iodine.

October 10, 1935, B. M. R. was +10, pulse 96 .

October 24, 1935, B. M. R. was - 15, pulse 60 . One week ago patient was feeling wonderfully. She had not realized how nervous she had been; felt much quieter now. Four days ago she had had a sudden attack of tetany preceded by headache and has had an attack of carpopedal spasm every day since. Examination showed a definite change in the general picture since iodine medication. Patient was quiet and reposed, tremor was much diminished, Chvostek moderately positive, Trousseau positive at $1^{\prime} 40^{\prime \prime}$, serum calcium $8.2 \mathrm{mgm}$. and serum phosphorus $4.2 \mathrm{mgm}$.

\section{Second admission}

Patient was admitted to the metabolism ward for study on November 6, 1935. Four days before entry she had contracted a cold which "settled" in her chest. There has been a productive cough with chest pain. In addition to points already covered in notes from the outpatient clinic, her history contains the following items.

She has been subject to head colds, last and most severe of which occurred in May 1935. At this time she had a temperature of $103^{\circ} \mathrm{F}$. and was in bed for six days. Following this she was quite run down. She has had increasing headaches of late; generalized, never severe, averaging about two a week for the last 2 months, and having also preceded the recent attacks of tetany. During the past 5 months, there have been occasional attacks of blurred vision lasting about ten minutes; no diploplia. Shortness of breath, complained of in first admission, has been noticed again recently; no palpitation. On two occasions recently she has been awakened at night by a sense of suffocation which has passed off rapidly. There was no edema and only occasional nocturia. Catamenia was regular with no change in flow or molimina. Memory was good. Lately patient has had to restrain herself from becoming irritated with her family.

Dietary history. Patient has always liked milk and for past year has averaged $1 \frac{1}{2}$ quarts a day, a moderate amount of butter, cheese once a week, and occasionally nuts. She eats green vegetables and fruit daily.

Physical examination. Patient was a well developed, 
well nourished, composed woman with moderate exophthalmos with stare, no lid lag, and slight fine tremor. There was a thyroidectomy scar with thyroid tissue definitely palpable. Right lobe measured $3 \times 3 \times 2 \mathrm{~cm}$. At left upper pole there was a rounded mass, $3 \mathrm{~cm}$. in diameter. The body of left lobe was slightly enlarged. No thrill or bruit was present. There were coarse râles at left base posteriorly consistent with bronchitis. On dorsum of hands between first and second metacarpals there were fibrillary twitchings; no muscular twitchings were seen elsewhere. Chvostek $2+$, Trousseau positive at 45", associated with considerable pain. No lens opacities were visible. Impression: hypoparathyroidism; iodine remission of thyrotoxicosis; acute upper respiratory infection with bronchitis.

November 7, 1935, patient had an attack of tetany with carpopedal spasm and spasm of small muscles of feet. Calcium gluconate, 1 gram, was given intravenously and 2 grams more intramuscularly. Tetany continued until after the third injection.

November 8, 1935, tetany recurred; patient was slightly apprehensive and uncoöperative, suggesting mental change of tetany. Calcium gluconate, 2 grams, was injected intramuscularly with relief of spasm. $\mathrm{Pa}-$ tient's coughing was still present.

On November 9, 10, and 11, daily attacks of tetany were relieved with 1 gram calcium gluconate intramuscularly. Mental outlook was improved.

November 12, 1935, electrical reactions taken by Dr. Robert Schwab showed 50 per cent lowered electrical threshold during latent tetany. Active tetany occurred later with cramps in arms and calf muscles, paresthesias. Chvostek continued strongly positive. Calcium gluconate, 2 grams, was injected intramuscularly with subsequent relief. The first period was started November 12, 1935.

November 13, 1935, upper respiratory infection had subsided and chest was clear. Chvostek and Trousseau signs remained strongly positive but there was no active tetany; patient was more cheerful. No further calcium gluconate was administered.

From November 14 to 27 patient spent most of her time in bed but was allowed up for short periods. She had no further active tetanic spasms but from time to time had paresthesias and some pain in small muscles of feet. Chvostek and Trousseau signs remained positive throughout.

$\mathrm{X}$-rays, November 26, 1935 : density of bones of hands and forearms normal, normal trabeculation; skull showed some calcification in dura at the vertex; bones of spine and pelvis showed nothing unusual.

November 27, discharged home. Patient was still having mild paresthesias in both hands and feet but no definite tetanic spasms. No signs of thyrotoxicosis were present except residual exophthalmos and palpable goiter. Iodine was omitted in order to allow thyrotoxicosis to reappear. A low calcium intake was to be continued.

Observations in Outpatient Metabolism Clinic

December 4, 1935, B. M. R. was -6, pulse 66, weight $57.7 \mathrm{kgm}$.
December 11, B. M. R. was +21 , pulse 96 . Patient was still having occasional cramps in feet; both hands felt tight yesterday, no numbness or tingling; occasional palpitation; no nervousness or excitement. Serum calcium was $7.6 \mathrm{mgm}$., serum phosphorus $4.7 \mathrm{mgm}$., and serum phosphatase 6.0 units.

December 18, B. M. R. was + 33, pulse 114. Cramps in feet have continued. She had been active a whole week and felt fidgety. There was definite increase in perspiration; she was hungry and eating ravenously. Chvostek was present but diminished; Trousseau could not be obtained in two minutes. Her hands were clammy with increased tremor. There was definite lid lag, and forehead did not wrinkle. Thyroid remained the same size; bruit and thrill were present over nodule on left side.

December 26, 1935, B. M. R. was +25 , pulse 126 , weight $54.1 \mathrm{kgm}$. Five days ago patient contracted a "cold" with cough and chest pain for last two days. There was no further tetany or tingling; no further blurring of vision; Chvostek faint. Serum calcium was $9.0 \mathrm{mgm}$., serum phosphorus $4.2 \mathrm{mgm}$., and phosphatase 5.0 units. She is continuing on a low calcium diet.

January 2, 1935, B. M. R. was +3, pulse 78. Upper respiratory infection has been relieved. There was no nervousness or sweating. Appetite was as good as ever. The only medication has been vaporub; no foods have been eaten which might have contained iodine. Faint Chvostek was present on right side only, no Trousseau after $13 / 4$ minutes.

January 8,1936 , B. M. R. was +1 , pulse 60 ; there was definite decrease in appetite. Patient menstruated for first time in 8 weeks. Serum calcium was $8.2 \mathrm{mgm}$., phosphorus $4.4 \mathrm{mgm}$., and phosphatase 4.7 units.

January 15, B. M. R. was +7 , Chvostek positive, and Trousseau negative.

January 22, B. M. R. was +19 , pulse 78 , weight 55.3 kgm. Patient was still having cramps in forearms, fingers and feet, was occasionally dizzy, and feels "touchy." Her appetite was excellent. Chvostek was +2 . Trousseau positive in 45". Serum calcium was $7.0 \mathrm{mgm}$., phosphorus $4.3 \mathrm{mgm}$., and phosphatase 4.9 units.

January 29, B. M. R. was +37 .

\section{Third hospital admission}

Patient was admitted to the metabolism ward for study on January 29, 1936. Since discharge from hospital nine weeks ago she had coöperated well in adhering to a low calcium diet with intake of between 200 and $300 \mathrm{mgm}$. per day. She had taken no iodine since the last visit and has now completely recovered from the upper respiratory infection contracted five weeks ago. At this admission patient complained of some irritability and nervousness which have appeared during the past week. She had not been bothered by cold weather and had slept well. There had been a return of her ravenous appetite; one attack of diarrhea four days ago. Two weeks ago she had had one attack of blurred vision lasting a few minutes. 
Examination showed a slightly excited, well nourished patient. Exophthalmos was present in same degree as at the previous admission; stare was visible. At times a lid lag was present and a normal convergence. No lens opacities were seen with either slit lamp or ophthalmoscope. There was a fine tremor, the palms of the hands were moist. The thyroid nodules were approximately the same size as at her previous entry. Thrill and bruit were absent, Chvostek positive, Trousseau negative.

The patient was immediately placed on the same standard neutral low calcium diet with same control fluid intake as at the second admission. Three metabolic periods of three days each were observed after a preliminary five days of the diet. During the fifteen days of ward study she showed signs of continued thyrotoxicosis. Except for last four days there was a fever between 90 and 100 every afternoon. There was no evidence of infection. The pulse rate remained elevated between 100 and 125. Except for two occasions, the Chvostek sign was positive during this admission, varying from faintly to strongly positive. Although the Trousseau sign was negative throughout, there were occasional complaints of tingling and slight cramps in both hands and feet. There was one dizzy spell; no blurred vision or headache. She had a normal menstrual period immediately after entry. Routine blood and urine studies were negative.

Patient was discharged February 12, 1936. Diagnosis : recurrent thyrotoxicosis, hypoparathyroidism with latent and mild tetany.

\section{Follow-up observations}

March 4, 1936, B. M. R. was +25 , pulse 102 , weight $56.3 \mathrm{kgm}$. Patient had been active, not minding the unusually cold weather, and had gained weight with a ravenous appetite. Examination on this admission was the same as during her third hospital admission. Chvostek was positive and Trousseau negative after $1 \frac{1}{2} \mathrm{~min}$ utes. Electrical reactions showed that 2 milliamperes less current were required to obtain a response than on November 12, 1935. Serum calcium was $8.6 \mathrm{mgm}$., phosphorus $5.4 \mathrm{mgm}$., and phosphatase 3.0 units. Patient was started on Lugol's solution.

March 18, 1936, B. M. R. was +9, pulse 90. There were mild symptoms of tetany; Chvostek and Trousseau signs were positive. Serum calcium was $8.6 \mathrm{mgm}$. and phosphorus $4.6 \mathrm{mgm}$. Patient was started on viosterol, 50 drops a day, and was to continue on a low calcium diet and Lugol's solution.

April 1, 1936, B. M. R. was -7, pulse 72. Symptoms of tetany were less than at her last visit. Residual exophthalmos was present but there were no signs of active thyrotoxicosis. Chvostek faintly positive and Trousseau positive at $1^{\prime} 30^{\prime \prime}$, produced less active cramp than on March 18. Serum calcium was $8.8 \mathrm{mgm}$., and phosphorus $4.5 \mathrm{mgm}$.

April 22, B. M. R. was +2 , pulse 72 , weight 58.3 $\mathrm{kgm}$. Serum calcium was $8.2 \mathrm{mgm}$., phosphorus $4.6 \mathrm{mgm}$.
May 20, B. M. R. was +2, pulse 78, weight $56.2 \mathrm{kgm}$. Serum calcium was $8.4 \mathrm{mgm}$., phosphorus $3.6 \mathrm{mgm}$.

June 24, B. M. R. was +9 , pulse 84 , weight $54.1 \mathrm{kgm}$. Serum calcium was $8.5 \mathrm{mgm}$., phosphorus $3.2 \mathrm{mgm}$. There were no symptoms of thyrotoxicosis, but occasional paresthesias. Trousseau was positive in 45". There was no evidence of cataract. Patient has been continuing medication of cod liver oil, calcium lactate and iodine.

September 23, B. M. R. was +7 , pulse 84 , weight $53.1 \mathrm{kgm}$.

October 22, 1936, B. M. R. was +5 , pulse 78, weight $52.5 \mathrm{kgm}$. Just before onset of catamenia, two weeks ago, patient had questionable mild active tetany in right hand; Trousseau was negative.

\section{BIBLIOGRAPHY}

1. Aub, J. C., Bauer, W., Heath, C., and Ropes M., Studies of calcium and phosphorus metabolism. III. The effects of the thyroid hormone and thyroid disease. J. Clin. Invest., 1929, 7, 97.

2. Albright, F., Baird, P. C., Cope, O., and Bloomberg, E., Studies on the physiology of the parathyroid glands. IV. Renal complications of hyperparathyroidism. Am. J. M. Sc., 1934, 187, 49.

3. Aub, J. C., Albright, F., Bauer, W., and Rossmeisl, E., Studies of calcium and phosphorus metabolism. VI. In hypoparathyroidism and chronic steatorrhea with tetany with special consideration of the therapeutic effect of thyroid. J. Clin. Invest., 1932, $11,211$.

4. Albright, F., Bauer, W., and Aub, J. C., Studies of calcium and phosphorus metabolism. VIII. The influence of the thyroid gland and the parathyroid hormone upon the total acid-base metabolism. J. Clin. Invest., 1931, 10, 187.

5. Tibbetts, D. M., McLean, R., and Aub, J. C., Studies of calcium and phosphorus metabolism. XX. The high calcium excretion in exophthalmic goiter is not due to vitamin D deficiency. J. Clin. Invest., 1932, 11, 1273.

6. Hansman, F. S., and Wilson, F. H., Calcium and phosphorus metabolism in diseases of the thyreoparathyreoid apparatus. I. Calcium, phosphorus and total metabolism in hyperthyreoidism and the part played by the parathyreoid glands. Med. J. Australia, 1934, 1, 37.

Hansman, F. S., II. The problem of the mode of action of Vitamin D. Ibid., 1934, 1, 81.

7. Bauer, W., and Aub., J. C., Studies of inorganic salt metabolism. I. The ward routine and methods. J. Am. Dietet. A., 1927, 3, 106.

8. Fiske, C. H., and Logan, M. A., The determination of calcium by alkalimetric titration. II. The precipitation of calcium in the presence of magnesium, phosphate, and sulfate, with applications to analysis of urine. J. Biol. Chem., 1931, 93, 211.

9. Fiske, Cyrus H., and Subbarow, Yellapragada, The colorimetric determination of phosphorus. J. Biol. Chem., 1925, 66, 375. 
HYPOPARATHYROIDISM AND HYPERTHYROIDISM

341

10. Albright, F., and Sulkowitch, H. W., Personal communication.

11. Handy, Jones Otis, The volumetric determination of magnesia. J. Am. Chem. Soc., 1900, 22, 31.

12. Bodansky, Aaron, Phosphatase studies. II. Determination of serum phosphatase. Factors influenting the accuracy of the determination. J. Biol. Chem., 1933, 101, 93.

13. Bauer, W., Albright, F., and Cub, J. C., Studies of calcium and phosphorus metabolism. II. The calcum excretion of normal individuals on a low calcium diet, also data on a case of pregnancy. J. Chin. Invest., 1929, 7, 75.

14. Bauer, W., Aub, J. C., and Albright, F., Studies of calcium and phosphorus metabolism. V. A study of the bone trabeculae as a readily available reserve supply of calcium. J. Exper. Med., 1929, 49, 145.

Jaffe, Henry L., Bodansky, A., and Blair, J. E., The sites of decalcification and of bone lesions in ex- perimental hyperparathyroidism. Arch. Path., 1931, 12, 715.

15. Bogart, L. Jean, and Hastings, A. Baird, The calcum salts of bone. J. Biol. Chem., 1931, 94, 473.

16. Benedict, Francis Kano, A study of prolonged fasting. Carnegie Institute of Washington, 1915, Pub. No. 203.

17. Cope, Oliver, The surgery of subtotal parathyroidectomy. N. England J. M., 1935, 213, 470.

Churchill, Edward D., and Cope, Oliver, The surgecal treatment of hyperparathyroidism. Based on 30 cases confirmed by operation. Ann. Surg., 1936, 104, 9.

18. Alb, J. C., Do the pituitary and adrenal glands influence calcium or magnesium metabolism? $\mathrm{Tr}$. A. Am. Physicians, 1936, 51, 129.

19. Alb, J. C., Hypophyseal-parathyroid relationships. Medical School Program, Harvard Tercentenary Celebration, September 15, 1936.

20. Albright, Fuller. (To be reported.) 